\title{
About the "Buddhist View" on Russian Literature
}

\author{
Rinat Ferganovich Bekmetov \\ Ph.D. in Philology, Associate Professor, Department of Russian Literature and Instruction, \\ Kazan (Volga Region) Federal University \\ Email: bekmetov@list.ru
}

\section{Doi:10.5901/mjss.2015.v6n3s3p9}

\section{Abstract}

The article deals with the problem of interpretation of Russian classical literature texts through the prism of the conceptual and categorical framework of the Indo-Buddhist religious philosophy. The starting point of this study is the view considering Buddhism not only a traditional doctrine with a set of value-related meanings, but also a certain kind of an underlying universal "meta-language." The author of the article tries to explain the artistic consciousness of Russian writers represented by the text in terms of the "East-Centric" turning predetermined by the ambivalent cultural position of Russia (between the East and the West). Besides, the proposed model of classic works interpretation correlates with the statement of M.M. Bakhtin about the importance of involving remote cultural contexts in the process of understanding a particular literary phenomenon. The concept of "big-time" proposed in his days by the Russian philosopher has not yet exhausted. Verbal text is a kind of a "geographic" map, in which the brilliant author leaves marks that require conceptual decoding.

Keywords: Russian classical literature, Buddhist religious philosophy, image, consciousness, text, dialog.

\section{Introduction}

The "Buddhism and Russian Literature" issue is extremely complex and broad. However, despite the relative interest in it, its still requires scientific reasoning. Of course, there are literary studies that consider the forms of reception of the Buddhist system of images and motives in the works by Russian writers. However, these works, being limited by the historical context, explore only particular aspects and individual development lines of the complex problem without any attempt to systematize the Buddhist theme as a whole, build a sequence of the steps of its penetration into the depths of the Russian literary consciousness. There is an impression that Buddhist texts on the Russian soil are a "mosaic" of random, irregular "bursts," entered into resonance with the reasonable attitude of a certain writer. Meanwhile, the Buddhist element in the Russian culture has its own rather long history.

In addition, Buddhism is often interpreted by literary scholars rather narrowly, as a religious and philosophical tradition that emerged in the northeast of India approximately in the fifth century BC and then spread throughout the world and, primarily, the countries of Southeast Asia. These judgments are quite legitimate and even self-evident. However, seeing Buddhism only as a set of dogmatic notions means seriously impoverishing the Dharma teachings and ignoring the inherent metalanguage of spiritual contemplation, which is of universal anthropological nature. It is no coincidence that the Buddhist psychotechnology, which is mainly of the tantric nature (many-tentacled and well developed), became a certain key for $\mathrm{C}$. Jung in his explaination what was archetype as a phenomenon of collective unconscious. In the $\mathrm{M}$. Heidegger's concepts, one can hear echoes of the Zen Buddhist psychological doctrine, which, however, the German philosopher of the XX century himself never intended to hide. In this case, Buddhism is a kind of meta-theory, a common language for describing processes that are hard to verbalize and closely related to the image in his sensual guise. Hence, by the way, it would be logical to understand the style of creative behavior of Russian writers, which is manifested in literary writing, through the categories of the Buddhist philosophy, if we understand the Buddhist principle as a holistic view of the world. (We need to note that any productive communication involves meeting of minds filled with ready semantic visions. In this respect, based on the paradigm of an ideal experiment, it would be interesting to see in detail how a conditionally "Buddhist reader" decrypts the Russian model of the world, what he could potentially find in it for himself, and what he could accept or reject). This, in turn, prompts us to ask ourselves the theoretical question about the place of "religious literary criticism" in the system of humanities knowledge, about the correlation of such literary criticism with the secular science, about the possibility of a dialog of these strategies within the framework of the positive interaction culture.

Howbeit, Buddhism interpreted broadly provides an opportunity not only to analyze the empirical data, but also to 
deliver the essential issues in a much broader sense that brings the literary science to the boundary of contact with other sciences. The integrative nature of this goal setting is undeniable.

\section{Literature Review}

There were three lines of the Buddhist theme research: 1) scientific, 2) religious and philosophical, and 3) literary and artistic.

The first direction is associated with explanation of the "ethnographic" specificity of Buddhism, of how it adapted to the culture of the Russian regions. There are many literary works on this subject, and not only the studies of the past are addressed, but also of the present times, especially when you consider that in the 1990s, after the collapse of the Soviet Union, the interest in religions in Russia increased tremendously. Some of the newest works of this kind are works by A. Bernstein (Bernstein, 2012), H.S. Hundley (Hundley, 2010), P. Harrison (Harrison, 2010), E.S. Holland (Holland, 2014) and K.A.Waylen and colleagues (Waylen, 2012). They consider the issues of historical Buddhism functioning in the areas of its traditional spread in Russia (i.e. Kalmykia, Buryatia, and Tuva). These largely descriptive publications can be rightfully called historical and sociological.

The second direction focuses on the problems of the Buddhist dogmatics as compared to the dogmatic part of other faiths, mostly Christian, and more specifically, Russian Orthodoxy. In Russia, this direction was developed in the works by the philosophers of the "Silver Age," and in more recent times -in terms of objective rational knowledge -by professional Buddhism scholars (see for example: Safronova, 1997, 1998; Trofimova, 1992).

The third direction is the study of the forms and methods of figurative and literary assimilation of Buddhism. However, this assimilation is limited to the Russian classics of the late XIX - early XX century (L.N. Tolstoy, I.F. Annensky, and I.A. Bunin, for example). Other works on this topic include Schiffman, 1971, Woodward, 1970, Gorelova, 1996, Marullo, 1998. They discuss the historical and literary aspects of the Buddhist theme and emphasize the value of the era, the atmosphere of which was filled with interest in the East due to the crisis of the official Orthodoxy. Buddhism, as a meta-language, was not discussed in these or other similar writings.

\section{Research Methodology}

The main methods of our study include 1) hermeneutic, 2) structural-semantic, and 3) comparative.

The hermeneutic approach is associated with symbol as a literary phenomenon of consciousness. For a phenomenological literary scholar, the work to identify hidden and non-obvious senses in the symbol image does not transform into subjective arbitrariness when the biased position of the researcher directs the total of statements about the text along a strictly specified path. When P. Ricoeur emphasized the idea that "interpretation is a thinking process, which consists in deciphering of the sense hidden in obvious words, in revealing the levels of meaning embodied in the literal sense" (Ricoeur, 1993), he only expressed his reasonable attitude to natural interdependence of interpretation and symbol. Where the symbol reveals itself, one can always find an infinite reflective response motivated by the complex semantic nature of the "unusual" sign.

These judgments are supported by ideas expressed by U. Eco. For the Italian researcher, the cultural system conceived as an ordered set of signs corresponds to the concept of communication. U. Eco considered it necessary to emphasize that it is more efficient to analyze any sign system by singling out "constant mechanisms of thinking" in it (Eco, 1998).

It is appropriate to recall the words of M.M. Bakhtin that "if one cannot study literature in isolation from the whole culture of the era, it is even more detrimental to restrict a literary phenomenon by the era of its creation." And further "Trying to understand and explain the work only by the conditions of its era ... we will never understand its semantic background ... Semantic phenomena can exist in latent form, potentially, and be disclosed only within the semantic cultural contexts favorable for this disclosure..." (Bakhtin, 1979). This, as you know, is the essence of Bakhtin's concept of the "big time" as a cultural and chronological extent, in which ideas can remain unuttered in order to find voice in other "worldview conditions."

\section{Results}

\subsection{Buddhism in Russian literature and culture}

When people talk about Buddhism in the Russian cultural-historical perspective, they most often and reasonably have in 
mind the "Silver Age" -the age that contradictory integrated positivist principles of the XIX century with a steady focus on the dark "logos" -irrational, mystical, occult, lying on "other side" of human memory and consciousness. The "Silver Age" indeed included a "neo-Buddhist" element of psychotechnical nature. In some terms, it may have been an essential feature of the synthetic time, although any categoricality in this matter is not entirely appropriate, as it is a "hypertrophy" of a single research view. Suffice it to say, for example, that in the well-known poem by A. Blok "Night. Street. Lantern. Pharmacy ... " (Blok, 1962), we can see not only the images of the world repeated and closed loop (the circle time), but also -with account of the author's negative emotional and reflective evaluation - the "samsara wheel" that led the character in the maelstrom of deadly monotonous life, in whatever subject form it may be embodied. If, however, we formulate the question more broadly, referring to the genesis of the "Buddhistic" in the Russian culture of the epochmaking time, the answer usually comes down to outside influence (through the French poetic symbolism of the 1870s with its pessimism and attraction to the experience of cultures of the exotic East, inherited from romantic poets). However, the Buddhist component of the Russian spiritual thinking is of "autochthonous" nature and is based on the longstanding traditions of Russia's dialog with the Eastern world.

In fact, it is known that the composition of old Russian literature was determined by a significant number of translated texts. Among them, the tale "Barlaam and Joasaphat" has pride of place, being a unique monument of cultural "borderland" and translated to the ancient Slavic language from the Greek language, apparently, no later than in the XII century (Bekmetov, 2015). Since the time of the academician A.N.Veselovsky, this work has been considered an artistic option of Buddha's biography; the name "Joasaphat" is understood as a modification of the word "bodhisattva" -"the one who is on the path of enlightenment" as opposed to the "Buddha" -the one who is already "enlightened," "awakened," and has found the point of ontological support. Although in recent years the idea prevails, according to which the tale "Barlaam and Joasaphat" arose from non-Buddhist legends that existed in Central Asia (Kuznetsov, 1979), it does not change the overall situation connected with the concept of Buddhism transformation at its contact with the Christian doctrine. Besides, the assumption by V.N. Toporov, according to which the tale of Joasaphat penetrated into Kievan Rus not only due to the Greek mediation (as happened with the story of Indian origin "Stefanit and Ihnilat"), but almost directly -along with a set of motives in the ancient Russian arts and folklore (Toporov, 1960), has not lost the edge. The story about Joasaphat the Fair was included in Old Believers' art, in such a genre form as the Russian spiritual verse.

Official appearance of Buddhism was associated with the joining of the peoples of Turkish-Mongol origin who professed Buddhism (Buryats and Kalmyks) to Russia. This incremental process began around the end of the XVI century with the conquest of the Siberian land and actually ended in the early XVIII century. (Buddhist Tuva came under the protectorate of Russia in 1914, and thirty years later, in 1944, decided to join the Soviet Union, first as an autonomous region, then as an autonomous republic). The modern Russian historiography has reinforced in the view that there is dynamic parity between the two cultures and no bitterness in the dialog process despite the fact that the canonical Orthodoxy perceived Buddhism as a pagan belief. The mutual tolerance had its origins. On the one hand, the Russian authorities could not ignore the monumental spiritual culture that Buddhism objectively was. On the other hand, Buddhist peoples themselves perceived the new situation as the serving allegiance to the "white czar," the supreme ruler in the chain of karmic rebirths. Many Buddhists believed that Russian czars descended from Genghis Khan. Hence the sacralization of the monarch derived, which was typologically close to the form of extreme deference to him, typical of the Byzantine court ritual. However, it must be admitted that in the XVIII century, there was neither literary nor scientific research of Buddhism. Individual expeditions to Siberia intended to examine the ethnography of the peoples of the region; the Buddhist component was evaluated as a kind of local shamanism (which was true to some extent, given the extraordinary tolerance of Buddhism, its amazing ability to embed in someone else's worldview without antagonism and retain the habitual for a certain nation pantheon of gods). If we accept the viewpoint of M.M. Bakhtin, according to which any culture indicates world duality by combining the two opposite poles, official and popular, serious and festive, carnival and dogmatic, it is likely to be right to say that in the XVIII century, Buddhism opened itself better to the representatives of the low-level democratic strata of the Russian society. Thus, contacts with Siberian tribes and nations were inevitable for dissenters (Old Believers) who demonstrated more tolerant attitude to alien customs, language, and mythology than the supreme authorities.

We need to emphasize that the "educational" project related to Buddhism was truly implemented in Russia not in the XVIII, but in the XIX century, mainly in its second half. It was the time when the Buddhist "vector" of the Russian culture took shape due to systematic expeditions to the East and emergence of original scientific and academic schools, which raised the quality of Buddhist studies to the level of top European models (German and French) (see: Vasilyev, 1857). This, in turn, resulted in the necessity to comprehend Buddhism in the context of the Christian philosophy. Perhaps the most successful attempt of this kind was made by V.S. Solovyov for whom Buddhism was the first "negative 
element" in the world history. Taking the idea of life in the "Doctrine of God-manhood" as eternal suffering, V.S. Solovyov did not share the Buddhist passive acceptance of what is happening. He also considered the escape from reality to the abstract, the not fully explained nirvana, a fatal error that prevented the Buddhist religion from resisting the forces of the metaphysical evil (Solovyov, 1994). This philosophical position was also reflected in the literary criticism by V.S. Solovyov. Thus, evaluating the works of the Russian poetry of his time, he preferred to use the concept of "Buddhist sentiment," by which he meant a sense of endless pessimism that had spread, in his opinion, in the post-Pushkin era (Solovyov, 1990). (He perceived Pushkin as a poet of Christian joy, of the triumph of life over death). This vector of interest in Buddhism was reinforced in the oeuvre of I.A. Goncharov (especially in connection with his world tour described in the essay "Frigate 'Pallada"'), A.A. Fet, the translator of Schopenhauer's "The World as Will and Representation" (a work that was strongly influenced by the Buddhist doctrine), L.N. Tolstoy who reflected on the nature of death and struggled with the monocentrism of the Christian doctrine (we need to mention at least the Leo Tolstoy's rationalism characteristic given by N.A. Berdyaev: "I have always thought that Tolstoy's worldview is not a Christian, but more likely a Buddhist one" (Berdyaev, 1991)).

In XX century, the Buddhist component had at least the same focus and not only in the context of the "Silver Age." The Buddhist attitude is clearly seen in the oeuvre of M.M. Prishvin, a "contemplative" writer of the modern Russian literature, V.V. Ivanov, the author of the novels "We are Going to India," "Return of Buddha," "The Adventures of the Fakir," which were popular in the 1920s, V.T. Shalamov whose essay "On the Prose" is obviously aligned with the philosophy of Zen Buddhist poetic art, I.A. Brodsky whose complex structured works are read through Buddhist overtones, V. Pelevin ("Chapayev and Void"), and B. Akunin ("The Diamond Chariot").

\subsection{Buddhist meta-language and the literary character interpretation (the case of I.A. Goncharov)}

From the large list of names and the extensive number of works of Russian classical literature, we will take I.A. Goncharov's texts (the novel "Oblomov," 1859) and I.S. Turgenev (the cycle "Senilia," 1877-1883) for the procedures of hermeneutical analysis using the Buddhist meta-language.

It is noteworthy that during their lifetime, these writers conflicted with each other. As you know, I.A. Goncharov reproached I.S. Turgenev for plagiarism basing his position on a set of "unquestionable" arguments. Literary scholars who had the biographical material understood this position as not only a natural desire to defend the truth of the creative talent, which is understandable and predictable, but also a "disease" associated with the doubtful nature of the author of "A Common Story," which disease he similarly showed in other circumstances. What is more important is that in the Buddhist view, both writers showed conceptual unity, which was, however, expressed at different levels of the content. Their works contain semantic background signaling the presence of non-Christian anthropological constants.

We know that the image of Oblomov is extremely complicated. There are numerous interpretations of its origin and essence, but one of them is noteworthy (Krivolapov, 1994). It comes from the fact that Oblomov is antinomic by nature; he combines the poles that we must not oppose succumbing to the temptation of linear logic, but perceive them in a "strange" unity. In his words, actions, feelings and reflexes, we can see a system of attitudes to the world, which can be called "medieval." Oblomov is an ascetic, a Christian monk who retired from the world of "bestial passions" to the humble abode of quiet moral happiness.

In general, this image model sounds reasonable; but on closer analysis, it becomes evident that it reveals the "upper" layer of the author's consciousness focused on the historical and cultural context close to I.A. Goncharov. It is useful to see the downside of the polyphonic composition.

Indeed, Oblomov is a philosopher; his couch is a place of reflection, not just of sleep; hence the couch is both an attribute of the infinite bliss, and the topos of contemplation (in Buddhism, it has an analog in the form of a carpeted lotus throne or felt cushion - den in Tibetan; and the Buddha was depicted sitting on a throne or cushions (Beyer, 2001; Pankratov, 1998; Shakya, 1994)). The rented apartment in the Gorokhohvaya Street is not a cave, a skete, or a catacomb church of the first Christian martyrs, but rather a sloppy and multicolor oasis in the urban snowy desert; compare: "silk curtains," "carpets," "bronze," "china," "two couches," "screens with embroidered fairy birds and fruits" (Goncharov, 1979).

No less remarkable is the corporeal "shell" of Oblomov, which is devoid of sharp angles and tends to completed roundness (the circle semantics is reflected in the phonetic structure of the surname: three syllables with "0" -one stressed in the middle and two reduced). Oblomov's "white neck," "plump hands," and "soft shoulders" (Goncharov, 1979) are the indications of hedonism and effeminacy, which are aligned with the "puffy" Buddha images in the iconographic and sculptural traditions. A kind of feminine face features of the Buddha stem from the statement that his holiness is defined by multiple external attributes (32 core and 80 secondary), in which the female/feminine ones are not in the last 
place due to the embodiment of a kind and merciful love for all living things. Undoubtedly, there is no need to assume that all the attributes of the Buddha must be passed to Oblomov (including his golden skin, straight teeth, long fingers, wide heel toe, ear lobes of specific shape, ushnisha -a bump on the top of head). They are not and cannot be present in full, because Oblomov is not an illustration of the Buddha, but a general and hidden hint of him. The Buddha is a kind of "matrix," a perfect symbol, by which Oblomov is read as a real character. Because instead of "golden skin," Oblomov has "complexion <...> neither ruddy, nor dark, nor positively pale, but indifferent" (Goncharov, 1979), and this deviation from the "primary source" is the evidence that we see a version of him intended to add a purely author's shade of sense to the formed construct.

Similarly as the age of the character ("a man of 32-33 years of age" (Goncharov, 1979), there is, on the one hand, bright evangelical connotation of physical and spiritual maturity of crucified Christ, and, on the other hand, a situation that, contrary to expectations, does not end up with a full description of the character's portrait. This reflects the strength of the perturbing influence of the Buddhist principle on the unconscious thought of the author. The Christian connotation is described not by the roundness of the body, "too pampered for a man" [5: 8], but rather by gaunt leanness, severe simplicity with no frills. Buddhism, as we know, rejected the extreme asceticism and did not agree with "indiscriminate" sensual pleasures. Initially, the Buddha, like many Indian preachers of his time, indulged in mortification; however, having reached the highest point of exhaustion, he changed his position drastically. Truth and boundless austerity have become so distant concepts that when the Buddha after deliberation took rice porridge with milk from a girl, wandering Shramanas considered him a weak-willed apostate and left alone (Torchinov, 2013). Oblomov liked to eat, and had sore feelings when his stomach was empty, but it does not mean that he addicted himself to the sin of gluttony: "a gnawed bone" and "bread crumbs" in the first chapter are too expressive details to ignore them; these are the signs of the person's readiness in any circumstances to be content with "what God has sent."

Oblomov's laziness is a "normal state" (Goncharov, 1979), due to which one can leisurely ponder about the person. Oblomov represents the bottom line of arguments about him after the first three guests have left in the first chapter. The arguments are rhythmically repeated, and, on consideration, they clearly express the idea that 1) life is suffering, dukkha (man is constantly crushed to pieces in the search of immediate satisfaction); that 2) the suffering has reasons (they are embedded in a person's desires; it is the manifestation of trishna, the attachment to existence); that 3) the suffering can be overcome (this possibility opens up when a person removes himself from "empty desires and thoughts"); and that 4) man is able to overcome suffering by following the path leading to peace, living death, nirvana. As you can see, the links of the provided reflexion embody the Four Noble Truths of the Dharma teaching. After all, Oblomov is a hermit, a bhikkhu living by alms, a bodhisattva trying to fall out of the chain of rebirths, the karma. That is why he is "a chip," "extra," and so unlike "other people" (A frequent word used in conversations of llya llyich with Zakhar). The wheel of samsara, which must be stopped, is naturally mentioned in his speeches (in the form of a comparison: "write all the time like a wheel, without rest," "so when can I stop and rest?" (Goncharov, 1979)).

I.A. Goncharov even provides a description of Oblomov's method of internal self-immersion with reference to the preceding chain of births in the form, in which they pass in front of the consciousness of a pacified person:

"Oblomov quietly ensued into a state of coma that was neither sleeping nor waking. He merely let his thoughts wander at will, without concentrating them upon anything, in particular as calmly he listened to the beating of his heart and occasionally blinked his eyes. Thus he sank into a vague, enigmatical condition, which partook largely of the nature of hallucination.

In rare instances there come to a man fleeting moments of abstraction when he seems to be reliving past stages of his life. Whether he has previously beheld in sleep the phenomena which are passing before his vision, or whether he has gone through a previous existence and has since forgotten it, we cannot say; but at all events he can see the same persons around him as were present in the first instance, and hear the same words as were uttered then. So was it with Oblomov now" (Goncharov, 1979).

The resemblance of this imaginary state with the codified forms of Buddhist meditation seems amazing. Compare a short excerpt from the Mahayana treatise attributed to Ashvaghosha (the I century AD):

"Should there be a man who desires to practice "cessation," he should stay in a quiet place and sit erect in an even temper. His attention should be focused neither on breathing nor on any form or color. All thoughts, as soon as they are conjured up, are to be discarded, and even the thought of discarding them is to be put away<...>. If the mind wanders away, it should be brought back and fixed in "correct thought." It should be understood that the idea of "correct thought" is that thought, whatever it is, is consciousness only" (Torchinov, 2005).

Curiously, the servant Zakhar also delivers Dharma semantics, not directly, but through the Orthodox Vedic word, in the attraction and repulsion to which Buddhism had been formed. The fact that Zakhar shows no zeal in cleaning the room is explained not only by the trivial laziness, with which he is infected like with illness. If you get a grasp of the 
dialogs of the first chapter, you can find that this impurity is related to the prudent use of someone else's lowest life, be it a bug or a mouse, as in Hindu temples; compare: "And he seemed to be thinking: "There cannot be normal sleep without bugs." (Goncharov, 1979). Even the "red spot" that appeared on Zakhar's forehead during the conversation with the master is an attribute of his "belonging" to Hinduism. It should be said that the character does not sleep in prone position as we are accustomed to think, and, according to the author, "is used to spend time sitting steeped in slumber" (Goncharov, 1979). ("Steep in slumber" recalls the posture of a Buddhist monk in silence contemplating the emptiness of his own consciousness; it is a "meditating" posture, although the word "meditation" derives from Latin "reflection").

The Vedic subtext is noticed in the image of Andrey Stolz, when the character says that "the normal destiny of a man is to live four seasons, that is four ages without skips, and to bring the life vessel to the last day of life without spilling a single drop in vain" (Goncharov, 1979 ). The meaning of this phrase is that the evolution of life is preferable to revolutionary ideas. In addition, the "four seasons" emphasize the cyclic completeness of human destiny. However, if you read into the words of the character and move the focus from the "seasons" to the "times of the age" (thus not omitting the conspicuous explanation "that is"), taking into account the long-standing relationship of Stolz with Oblomov, the interpretation scheme will be different. The fact is that the life of every human being, according to Hindu philosophy, is divided into four ashrams, each about twenty years long. The first years he is a brahmachari, a "student" because he is studying the science of existence preserving natural chastity. In the following years, he is a grihastha, "the one who is acquiring a family, builds a house, and multiplies welfare." Then, he is a vanaprastha, "the one who is engaged in pious deeds and comprehends the past life," and then he becomes a sannyasi, a "hermit" who refuses from his name and leads a modest wandering life. Hindus emphasize that a person can voluntarily become sannyasi in his young days, and there is nothing reprehensible in this act. India highly revered such people, without condemnation of those who remained on the stage of grihastha, a respectable layman abiding by the moral law. There is only on truth, but the roads leading to it are numerous. Finally, Stolz declares the teleological fullness of the life process, while Oblomov ontologically reaches it. Their relations fit into the typology of a "layman" and a "saint" -not the two poles of the European culture ("secularity" I "sacredness"), but, as in India, the two interdependent sides of the same phenomenon.

\subsection{The Buddhist mood and the existential "project" (the case of I.S. Turgenev)}

What caused the appearance of a Buddhist text in the works by I.S. Turgenev? Let us divide the answer into two parts, based on the dual nature of the creative thinking of the Russian writer. We need to recall that, according to researchers, the spiritual "substrate" of Turgenev's personality shows two components: the "light," "daily," "Apollonian" one and the "dark," "nightly," "strange" one (Toporov, 1998). The former was associated with rational representation, due to which Turgenev traditionally is perceived as a master of plastic forms bearing the stamp of subtle psychologism. The latter with the sense of existential angst, hidden fear of the depth of the unfathomable, which was manifested in the whole set of phenomena, from the obsessive desire not to get sick with cholera to the perception of nature as sensory-metaphysical instance indifferent to human beings.

In the first case, the "Buddhistic" was part of the cultural horizon, which Turgenev undoubtedly had assimilated as a European-educated writer. He had read a lot about Buddhism; Buddhism was part of his vision due to studying German philosophers (Schelling, Hegel, Fichte) during his study at the University of Berlin and communicating with classics of French literature who were distinguished for their interest in exotic forms of world order (Sh. Bodler, for example). In this guise, Buddhist texts can be found in some works of authorship. For example, in "Song of Triumphant Love" (1879) written on behalf of an anonymous author of an "ancient Italian manuscript," the Dalai Lama who "dwells on Earth in the form of a silent man with narrow eyes" (Turgenev, 1967) is mentioned to create oriental flavor. This image is supported by a casual remark by Valerie about the strange and incomprehensible behavior of Mucius who had traveled around the East: "What if he joined some new faith in India?" and a reference to Ceylon in connection with the character's playing a three-jet "snake" violin: "... I heard this song once on the island of Ceylon" (Turgenev, 1967). Typologically, the "Buddhistic" is implicitly adjacent to "Brahmin" (1881) - a text consisting of two sentences and composed in the form of a question about the mystery of the sacred, which is worshiped by men burdened with corporeal senses. It also includes a poem of the "Senilia" cycle characteristically entitled "Fell under the Wheel" (1882), which polemically develops the idea about earthly suffering, which does not hit a chord with the world of divine emptiness. (Groans of suffering and splashes of creek against a stone are phenomena of the same series for the subject of lyrical emotions). The "Wheel" in the title clearly echoes the "The Car of Juggernaut" -a comparison that was interpreted in a private letter of I.S. Turgenev to A.F. Otto-Onegin on October 9/21, 1872 ("... Who wants to imitate an Indian fakir? Those, at least, believe that being crushed, they go straight into the divine "nirvana," but we do not share their views and will simply be crushed -and that's the end" (Turgenev, 1967), and in a small art passage from the novel "Virgin Soil" (1876), which is the latest one in the series of 
major works by the writer ("The Indians threw themselves under the Car of Juggernaut... it crushes them and they die in bliss. We also have a Juggernaut... It crushes us, but does not beautify us" (Turgenev, 1967)).

In the second case, the "Buddhistic" is present little by little, as a conceptual moment, attracting image and motive details psychologizing the thought to the point of emotional lift. Buddhism is found concentrated in "Senilia" as disparate text fragments making up the chain of senses that are "non-obvious" at the ordinary reading. For example, the poem "The Dog" (1878) is based on the Buddhist understanding of the world as a single principle -a single continuous gyre of all living things. The "Dog" depicts the situation of self-immersion of a man on the verge of death; the text is full of symbolism of life and death confrontation: on the one hand, "room," "I," "dog," "tremulous light," and on the other hand, "storm," "death," "cold wing" (Turgenev, 1967). The link of the "fragile live" in the poem are "eyes" -the ontological organ of the last, non-verbal dialog before going into the abyss. The external surrounding of the situation seems to point at the Christian aspect of the mythopoetical symbolism. In this regard, the "room" is indeed reminiscent of a "monastic cell," the "tremulous light" localized in the "I" and the "dog" reminds of a life-giving candle, and the "terrible, violent storm" howling in the "yard" is associated with the harsh northern landscape. Moreover, the very picture of the "dialog" of a man and a dog, at first glance, is logical to be considered in the context of the Christian lives of the men of faith who had taken refuge in the skete with a tame animal (compare, for example: the Byzantine legend of elder Gerasimov who healed a wounded lion and took to his monastery, at John Moschus' in his "The Spiritual Meadow" (Byzantine Legends, 2004)). This seems to bespeak reasonably the individual author's transformation of the Christian view of the world in connection with the self-awareness of the author imbued with the spirit of pessimism and lack of will. All this is true, but Turgenev's intention is based on the same idea of intimately unifying connection of the living prime cause in the Universe; and it is just what puts the world in the "circular rim" of the soul soothing silence, moving from one dumb "eye" to another. It is appropriate to recall one of the theses, which the Zen Buddhist practice is based on, that any knowledge cannot be transferred with an abstract word, but only with a subtle bodily gesture, particularly, in a silent eye movement (always addressed "from teacher to student"). In addition, it should be noted that the experience of Buddhist meditation was based on the contemplation of what is subject to death and decay, so that the meditator could really estimate, without verbal distractions, the measure of his own affection for the absurd and earthly things. I.S. Turgenev in "The Dog" seems to avoid the contemplation line, as instinctive attachment to the living wins the emptiness and entropy of the other world here. In general, however, the scheme of putting the character in static long meditation near what is perishable and destroyable remains in force, although with an estimate different from the Buddhist one. (The Buddhist contemplation of death with a hint of carnivalized laughter is shown more straightforwardly in "The Skull", 1878 (Turgenev, 1967)).

In "The Monk" (1879), which is a "Christian" poem judging by the set image units ("cold floor of the church," "sweet prayer," "monk"), I.S. Turgenev's line of reasoning about the forms of a man's riddance of his own "I," which is "painful," "nasty," "hated," are given a poetic form (Turgenev, 1967). It is indicative that the writer used the personal pronoun "I" eight times, and in two places in the text, he set it in italics, making it clear that the "l" in this case was an object of cognition. An interesting fact is that the traditional Christian teaching considers prayer a kind of locus of the meeting of God and man perceiving him; and the "I" in this communication is not so much reduced and neutralized by a man, as dissolved in the divine, taking communion to it consciously, through the right choice. Total rejection of human being as part of samsaric existence is one of the cornerstones of Buddhism. Christianity has dual attitude to human being, though the said position is familiar to it in the most mystical schools. Hence, perhaps, it will not be a serious mistake to assume that in "The Monk," I.S. Turgenev interpreted a Christian prayer in an almost Buddhist manner (compare Turgenev's confession in the letter to E.E. Lambert dated August, 26/September, 8, 1864: "... I am not a Christian as you understand it, and, probably, as anyone else does" (Turgenev, 1967)).

It is remarkable that in the near located poem "The Prayer" (1881), the writer quite clearly pointed to the impossibility to experience the genuine thrill in a prayer to an abstract "god" of the German idealist philosophy and an imagery God of the Christian teaching: in all cases, the ulterior motive to appeal to the divine is miracle and its anticipation. Meanwhile, rationally thinking Turgenev contrasts uncertainty of anticipation with hedonistic morality with its open fullness of living each flash of the life ("And so: let us drink and be merry") and (it is worth underlining!) with an internal prayer "face-to-face," without any distraction, in the modest specificity of the upcoming existence -in the Buddhist way.

("Christ" by I.S. Turgenev (1878) tells the story of just such a desire to find true humanity in issues of faith, so the image of Christ in the text can be read as "reincarnation of the living bodhisattva" in the "lower village church," although in fact, Christian designations here, of course, remain in force. We should note in this regard that Turgenev's Christ is very close to the description of renowned Tertullian's passages depicting Christ in a much-humanized form -"in rags," "bearded," "with sad eyes." It is legitimate to relate Turgenev's Christ to the "soil" representations of Him, the more so in the very text, there are indications of that: a crowd of peasants is particularly compared by the writer with "mature ears," 
and Christ is supposed also to be an "ear" -the one affected with a "wave of the slowly blowing summer wind" (Turgenev, 1967)).

Buddhist motives can be found in the poem "I feel pity ..." (1878). This text is clearly divided into two parts. The first part, marked with the anaphora "I feel pity" ("for myself," "for all living," "for children and old people"), seems to again affirm the priority of the Christian system of values in the author's view of the world. The second part, on the contrary, uses the rhetorical question ("How do I get rid of this pity?") to remove the natural compassion of the lyric "I," bringing it to the circle of the in-depth sense of self. The "Buddhistic" becomes their parallel, namely: "suffering" as the destiny of every living creature on earth, "desire" as the cause of any "suffering" (sympathy is suffering, too), the need to overcome the "desires," the basis of the path that is supposed to lead to "liberation." Not randomly, the method of getting rid of "pity" and "boredom" is proclaimed in the poem as envy of stones, as stones embody serenity -the one that a reasonable person associates with the "nirvana."

\section{Conclusion}

In the 1890s, E.M. de Vogüe called the Russian culture a "Buddhist" one, meaning its tendency to "conservatism" (de Vogüé, 1892). In Soviet times, N.Ya. Berkovsky recognized the appropriateness of the general views of the French critic and noted that "Buddhism" of the Russian consciousness is a simple estimate that has no relation to reality and is caused by sharp distinction of French national aesthetics from Russian (Berkovsky, 1975).

In our opinion, "Buddhism" in Russian literature with its "universal sympathy" is not fiction, but a phenomenon that exists and that should be considered in two ways: 1) as an object of description and cognition; and 2) as an analysis strategy with a special, historically formed metalanguage. Only in this case the above interpretation of literary works will not look like a postmodern experiment, a scientific "game." Classical literature needs contextual reading based on the principle of reasonable and calm complementarity. The text of verbal classics is a "map," in which a brilliant author leaves multiple multidirectional signs. Their deciphering in the light of cultural systems is the key to permanent interest in the literature of the past.

\section{Acknowledgements}

The author would like to express the Department of Russian Literature and Teaching Methodology of the Kazan (Volga) Federal University and especially to my colleagues: Doctor of Philology Professor Albina Mazgarovna Sayapova and Candidate of Philology Associate Professor Marsel Ildarovich Ibragimov who kindly agreed to read the manuscript and provided valuable remarks.

\section{References}

Bakhtin, M. M. (1979). Aesthetics of Verbal Creativity. Moscow: Iskusstvo.

Bekmetov, R.F. (2015). The Indo-Buddhist System of Images in Old Russian Literature: The "Barlaam and Joasaphat" Tale as a Monument of Cultural Borderland. Filologicheskye Nauki. Voprosy Teorii i Praktiki. 2(44): in 2 parts, part 1. (33-36). http://www.gramota.net/materials/2/20/2015/2-1/7.html.

Berdyaev, N.A. (1991). Leo Tolstoy. In: N. A. Berdyaev, About Russian Philosophy, in 2 parts, part 2. (38-43). Sverdlovsk: Ural University.

Berkovsky, N Y. (1975). On the Global Significance of Russian Literature. Leningrad: Nauka.

Bernstein, A. (2012). More alive than all the living: Sovereign Bodies and Cosmic Politics in Buddhist Siberia. Cultural Anthropology. Vol. 27, Issue 2, May. 261-285.

Beyer, S. (2001). Magic and ritual in Tibet. Delhi: Motilal banarsidass publishers private limited.

Blok, A.A. (1962). Complete Works and Letters: 8 volumes. Volume 5. Moscow: Nauka.

Vasilyev, V.V. (1857). Buddhism and its Tenets, History and Literature. St. Petersburg: Typography of the Imperial Academy of Sciences.

Byzantine Legends (2004). St. Petersburg: Nauka.

Goncharov, I.A. (1979). Collected Edition: 8 volumes. Volume 4. Moscow: Khudozhestvennaya Literatura.

Gorelova, A.A. (1996). L.N. Tolstoy and Buddhism. Tolstoy and Religion. Moscow: Peoples' Friendship University of Russia. 54-62.

Hundley, H.S. (2010). Defending the Periphery: Tsarist Management of Buriat Buddhism. The Russian Review. Vol. 69, Issue 2, April. 231-250.

Harrison, P. (2010). A scientific Buddhism? Zygon: Journal of Religion and Science. Vol. 425, Issue 4. 861-869.

Holland, E.C. (2014). Buddhism in Russia: challenges and choices in the post-Soviet period. Religion, State and Society. Vol. 42, Issue 4. 389-402. 
Krivolapov, V.N. (1994). Again about "Oblomovism." Russian Literature, 2, 27-47.

Kuznetsov, B.I. (1979). The Tale of Barlaam and Joasaphat (to the question about the origin). Proceedings of the Old Russian Literature Department. Vol. 33, 238-245.

Marullo, Th.G. (1998). If you see the Buddha: Studies in the fiction of I. Bunin. Evanston: Northwestern University press.

Pankratov, B.I. (1998). The Iconography of Tibetan Buddhism (in connection with the publication of the book by L.N. Gumilev "Old Buryat Painting"). In: Countries and Peoples of the East. Issue 29. (289-301). St. Petersburg: Petersburgskoye Vostokovedenye.

Ricoeur, P. (1993). Existence and Hermeneutics. In: The Phenomenon of Man. (312-325). Moscow: Vysshaya Shkola.

Solovyov, V.S. (1990). Literary Criticism. Moscow: Sovremennik, 67-104.

Solovyov, V.S. (1994). Reading about God-Manhood. Rhymes and Poems. From "Three Conversations ...." St. Petersburg: Khudozhestvennaya Literatura.

Safronova, E.S. (1997). Buddhism and Christianity in Russia: the History of the Relationship. Religion, the Church in Russia and Abroad. 9(10): 90-100.

Safronova, E.S. (1998). Buddhism in Russia. Moscow: RASS.

Toporov, V.N. (1960). Dhammapada and Buddhist Literature. In: Dhammapada. Moscow: Vostochnaya Literatura, 5-55.

Toporov, V.N. (1998). "Strange" Turgenev (four chapters). Moscow: The Russian State University of Humanities.

Torchinov, E.A. (2005). Religions of the World. The Experience of the Ultramundane. Psychotechnics and Transpersonal States. St. Petersburg: Azbuka Klassika, Petersburgskoye Vostokovedenye.

Torchinov, E.A. (2013). Introduction to Buddhism. St. Petersburg: Amfora.

Trofimova, E.A. (1992). The Light of Synthesis: Buddhist Motives in the Heritage of N.K. and E.I. Roerich. Orient. 1. 51-57.

Turgenev, I.S. (1967). Complete Works and Letters: 28 volumes. Volume 13. Moscow: Nauka.

Shakya, M.B. (1994). Iconografy of Nepalese Buddhism. Kathmandu: Published by Handicraft Association of Nepal.

Schiffman, A.I. (1971). Leo Tolstoy and the East. Moscow: Vostochanya Literatura.

De Vogüé, E.M. (1892). Le roman russe. Paris.

Waylen, K.A., Fischer, A., McGowan, P.J.K., Milner-Gulland, E.J. (2012). Interactions between a Collectivist Culture and Buddhist Teachings Influence Environmental Concerns and Behaviors in the Republic of Kalmykia, Russia. Society \& Natural Resources: An International Journal. Vol. 25, Issue 11. 1118-1133.

Woodward, J.B. (1970). Eros and nirvana in the art of Bunin. The modern language review. Birmingham. Vol. 65, Issue 3. 576-586.

Eco, U. (1998). Missing Structure. Introduction to Semiology. St. Petersburg: Nauka. 
ISSN 2039-2117 (online) ISSN 2039-9340 (print)
Mediterranean Journal of Social Sciences MCSER Publishing, Rome-Italy
Vol 6 No $3 \mathrm{~S} 3$ May 2015 